Научная статья

УДК 811.512 .31

DOI: $10.18101 / 2305-459 X-2020-4-58-69$

\title{
СЕМАНТИКА ОБСТОЯТЕЛЬСТВЕННОГО СЛОЖНОГО ПРЕДЛОЖЕНИЯ В БУРЯТСКОМ ЯЗЫКЕ И ЯЗЫКОВАЯ КАРТИНА МИРА
}

\author{
(C) Скрибник Елена Константиновна \\ доктор филологических наук, профессор, \\ Университет Людвига Максимилиана \\ Германия, 80539, Мюнхен, ул. Людвигштрассе, 31/III \\ skribnik@lmu.de

\section{(C) Даржаева Надежда Баировна} \\ доктор филологических наук, старший научный сотрудник, \\ Институт монголоведения, буддологии и тибетологии СО РАН \\ Россия, 670047, г. Улан-Удэ, ул. Сахьяновой, 6 \\ dnadezhda@mail.ru
}

\begin{abstract}
Аннотация. В статье излагаются наблюдения над семантикой обстоятельственного сложного предложения в бурятском языке с точки зрения отражения в нем элементов национальной картины мира. Для бурятского (и для других монгольских языков) характерно необычно большое количество конструкций с обстоятельственными придаточными в рамках стандартных семантических типов, что заставляет задуматься о дополнительных семантических дифференцирующих параметрах. При анализе выяснилось, что это обусловлено выражением отношений между событиями действительности не только нейтрально, но и в регулярном соотнесении с системой ожиданий и оценкой по различным параметрам (качественная, количественная, прагматическая оценка). Тем самым в синтаксисе сложного предложения кодируются важнейшие компоненты бурятской картины мира - социально значимые нормы и координаты поведения, представления о характере протекания событий в природе и социуме.

Ключевые слова: синтаксис монгольских языков; обстоятельственное сложное предложение; синтаксическая семантика; оценка; несоответствие ожиданиям; картина мира.
\end{abstract}

Благодарность. Статья подготовлена в рамках государственного задания (ХІІ.193.1.5. Ментальность монгольских народов в зеркале языка, номер госрегистрации № АAАА-А17-117021310266-8).

\section{Для цитирования}

Скрибник Е. К., Даржаева Н. Б. Семантика обстоятельственного сложного предложения в бурятском языке и языковая картина мира // Вестник Бурятского государственного университета. Язык. Литература. Культура. 2020. Вып. 4. С. 58-69.

\section{1. Введение}

Понятие «языковая картина мира» как отражение в языке совокупности представлений о мире у данного языкового коллектива является в последнее время одной из актуальных тем лингвистических исследований $[1 ; 8 ; 9 ; 13]$. 
Е. К. Скрибник, Н. Б. Даржаева. Семантика обстоятельственного сложного предложения в бурятском языке и языковая картина мира

Подчёркивается, что это явление многоуровневое: сюда вовлечены фонетика, морфология, лексика и паремиология, но также и синтаксис; при этом большинство исследователей работают на уровне лексикологии и паремиологии, поскольку они дают наиболее прямой выход на значимые под этим углом зрения особенности семантики. Национальная языковая картина монгольского мира остается малоисследованной, хотя в последние годы появился ряд работ, посвященных этой теме: Р. В. Бухаева [4] (картина мира представляется через стереотипы речевого общения), М. Г. Шкуропацкая и Даваа Ундармаа [14; 15] (через ассоциативные поля определенной тематической группы слов - зоонимов), Т. Б. Тагарова [12] (через характеристики образа человека), 3. Д. Бардаханова [2] (через охотничью лексику) и др.

Синтаксическая семантика до сих пор была недостаточно включена в исследования картины мира; настоящая статья предлагает некоторые наблюдения над семантикой обстоятельственных сложных предложений именно с этой точки зрения.

Элементы картины мира наиболее четко проявляются при рассмотрении значащих единиц языка как системы в единстве со связывающими их разнообразными отношениями; вовлечение синтаксиса сложного предложения в исследование картины мира предполагает, что первоначально будут выявлены и описаны все сложные синтаксические конструкции, их инвентарь, которым располагает язык, - иными словами, отношения между событиями действительности, которые представлялись носителям языка достаточно значимыми, чтобы специально закрепить их в языке как отдельные единицы. Наши исследования бурятских синтаксических конструкций обстоятельственной семантики [11] предполагали в первую очередь именно выявление полного инвентаря таких конструкций; анализ их семантики на следующем этапе заставил нас задуматься об их семантической специфике по сравнению с русским и другими лучше изученными европейскими языками.

Обращает на себя внимание, что для бурятского (и для других монгольских языков) характерно необычно большое количество конструкций с обстоятельственными придаточными в рамках разных семантических типов: так, темпоральных конструкций в бурятском языке 65 (в халха-монгольском 103, в калмыцком 52); причинных конструкций 19 (в халха-монгольском 24, в калмыцком 20); целевых конструкций 12 (в халха-монгольском 8, в калмыцком 9); образа действия 10 (в халха-монгольском 20, в калмыцком 4); и т. д. При анализе выяснилось, что это обусловлено выражением отношений между событиями действительности не только нейтрально, но и в регулярном соотнесении с системой ожиданий и оценкой по различным параметрам. Если «grammars code best what speakers do most» [16, с. 363], то из этого следует, что в картине мира у монгольских народов важное место занимают социально значимые нормы и координаты поведения, общие знания о типичных последовательностях событий и других видов их взаимосвязи.

Понятию «оценка» посвящен большой массив литературы в рамках психологии, когнитивистики, когнитивной и функциональной лингвистики (см. обзор Bednarek [17]); в детальных классификациях типов оценки присутствуют 
такие категории, как «сценарии», «эстетические, этические и т. д. стандарты» или «системы ожиданий» (т. е. элементы картины мира). Однако подчеркивается, что хорошо проработана оценка в отношении лиц и предметов (agents \& objects), далее же «what is needed is an investigation into linguistic evaluations of events and a classification of the meanings expressed in their evaluation» [17, c. 156].

Наше исследование посвящено именно оценке событий и более того оценке отношений между событиями в полипредикативных конструкциях обстоятельственного типа. Обнаружены следующие дифференцирующие параметры: оценка качественная, в терминах 'хорошо' - 'плохо’ и с прагматическим оттенком ('полезно'); оценка количественная ('много' — 'мало'); соответствие/несоответствие индивидуальным ожиданиям либо социальным нормам ('неожиданно' / ‘не как принято'). Интересно, что разные семантические группы обстоятельственных конструкций тяготеют к выражению разных типов оценки и соответствия нормам; так, несоответствие ожиданиям сильнее всего проявляется в конструкциях образа действия и темпоральных, а оценка - в конструкциях причины и цели. В дальнейшем изложении мы рассмотрим основные семантические группы; условные и уступительные конструкции мы пока из описания исключим в связи с дополнительной спецификой их значений.

\section{2. Причинные конструкции}

Семантическая группа причины отличается наибольшим количеством конструкций, выражающих различного рода оценку: две отрицательных и три положительных, а также одна конструкция с количественной оценкой. Оценка выносится, как правило, с точки зрения говорящего.

2.1. В зоне негативной оценки используются две конструкции: одна с послелогом гэмээр и причастием прошедшего времени на $-h A H$, вторая причастнопадежная с причастием на $-h A н$ в исходном падеже.

Первая конструкция относится к книжному стилю; в ней и порождающая ситуация, и следствие оцениваются только негативно. Поскольку этот послелог происходит от слова гэм 'вина' в орудном падеже, т. е. опирается на социальную этическую или моральную оценку, порождающая ситуация всегда представляет собой человеческие действия, названия природных явлений и т. п. здесь невозможны.

(1) Архи уу-жа водка пить-cvb иимэ-л яба-һан-ай-м гэмээр такой-рcl aux-pc.pst-gen-poss1sg pstp бол-оо происходить- $\mathrm{pcl} \mathrm{pcl}[3 \mathrm{sg} / \mathrm{pl}]$ pc.prs

‘Из-за того, что я пил водку, вот это и произошло’ (БК $\left.{ }^{1}\right)$.

${ }^{1}$ Все приведенные в статье примеры взяты из Бурятского национального корпуса. URL: http://web-corpora.net/BuryatCorpus/search/?interface_language=ru (дата обращения: 10.09.2020). 
E. К. Скрибник, Н. Б. Даржаева. Семантика обстоятельственного сложного предложения в бурятском языке и языковая картина мира

Вторая конструкция с причастием на $-h A \mu$ в исходном падеже - $-h A t-h A A$ (особенно в сопровождении соединительного деепричастия от глагола боло-) характерна для разговорной речи. Большинство имеющихся у нас примеров с негативной оценкой порождающего события (не обязательно действий какого-либо лица), причем главная часть в таком случае как минимум нейтральна, чаще же оценивается также негативно:

\begin{tabular}{|c|c|c|c|c|}
\hline $\begin{array}{l}\text { (2) Шойнён } \\
\text { Ш. } \\
\text { шара } \\
\text { желтый }\end{array}$ & $\begin{array}{l}\text { ехээр } \\
\text { много } \\
\text { нюур- } a a \\
\text { лицо-refl }\end{array}$ & $\begin{array}{l}\text { унта-haн-haа } \\
\text { спать-рс.pst-abl } \\
\text { хабда-ша-нхай } \\
\text { отекать-intens- } \\
\text { pc.res[3sg/pl] }\end{array}$ & $\begin{array}{c}\text { боло-жо } \\
\text { aux-cvb }\end{array}$ & $\begin{array}{l}\text { бүдэн-тэг̆ } \\
\text { веснушки-рrop }\end{array}$ \\
\hline
\end{tabular}

2.2. Для выражения положительной оценки порождающей ситуации (и, соответственно, ситуации-следствия) в бурятском языке используются три конструкции: с послелогами haŭzaар 'благодаря' (букв. 'хорошестью', от haйн 'хорошо' с показателем инструментального падежа -AAp), ашаар 'благодаря' (букв. 'пользой', от аша 'польза'), урманда 'в честь того, что' (букв. 'в воодушевлении', от урман 'подъем духа, хорошее настроение, рвение' с показателем дательно-местного падежа -ДА), все в сочетании с причастием прошедшего времени. Первые два послелога различаются и стилистически: Танай haйгаap ‘благодаря вам’ (разг.) и Танай ашаар ‘благодаря вам’ (книжн.).

Послелог haйzaаp, в силу большей абстрактности своего значения, допускает природные явления в качестве порождающего события:

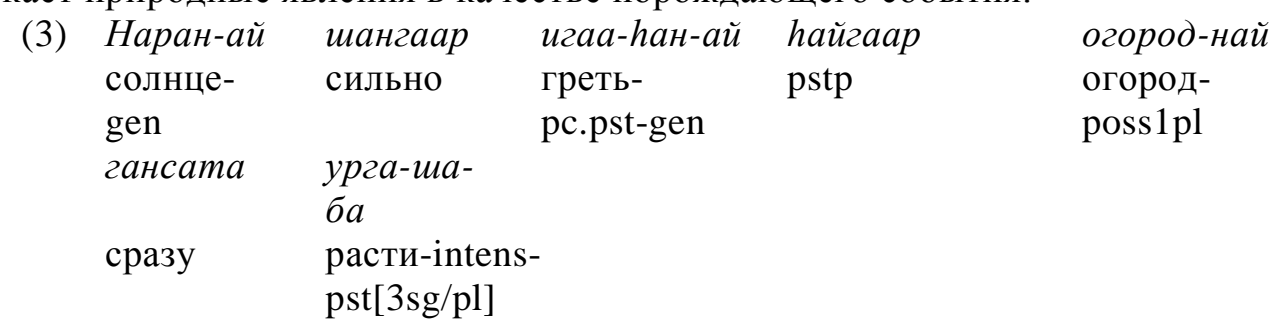

'Благодаря тому, что пригрело солнце, наши овощи (букв. огород) сразу пошли в рост'.

Конструкция с послелогом ашаар используется в корпусе преимущественно - но не исключительно - применительно к действиям и характеристикам людей, оцениваемым с прагматической точки зрения (говорящий подчеркивает, что они приносят пользу, тем самым позволяя осуществиться событию главной части):

(4) Бэлиээр-иие пастбище-асс Убэл-өө зима-refl

зубөөр
правильно
hайнаар
хорошо

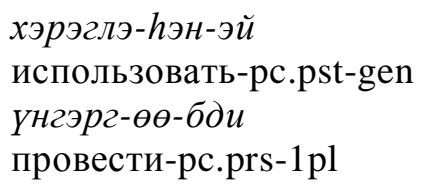


'Благодаря тому, что правильно использовали пастбища, хорошо перезимовали’.

$\begin{array}{lllll}\text { Емельянов } & \text { имагтал } & \text { райком-ой } & \text { нэгэ-дэхи } & \text { секретарь } \\ \text { Е. } & \text { именно } & \text { райком-gen } & \text { один-num.ord } & \text { секретарь } \\ \text { бай-hан-айн-гаa } & \text { ашаар } & \text { Улаан-Yдэ } & \text { ерэ-жэ, } & \text { обком-до } \\ \text { быть-pс.pst-gen-refl } & \text { pstp } & \text { У.-У. } & \text { приходить-cvb } & \text { обком-dat } \\ \text { Үндэр } & \text { тушаал-нуyд-ай } & \text { нэг-ье } & \text { эзэл-ээ } & \\ \text { высокий } & \text { должность-pl-gen } & \text { один-асс } & \text { занимать-pc.prs[3sg/pl] }\end{array}$

'Благодаря тому, что Емельянов был именно первым секретарем райкома, приехав в Улан-Удэ, занял одну из высоких должностей в обкоме'.

В конструкциях с послелогом урманда порождающее событие оценивается говорящим - либо же протагонистом нарратива - высоко положительно, в соответствии со значением слова, от которого этот послелог образован ('подъем духа, хорошее настроение, рвение'); в корпусе это только действия лиц, событие-следствие часто называет празднование или положительно оцениваемое событие другого рода.

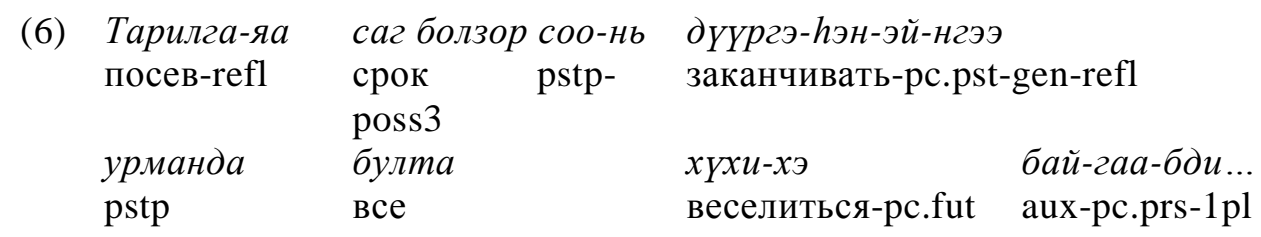

'В честь того, что вовремя закончили посевные работы, нам всем надо было бы повеселиться’.

2.3. Конструкция причины с количественной оценкой образуется послелогом ехэдэ (от слова ехэ 'много' с показателем дательно-местного падежа) и причастием прошедшего времени в родительном падеже. На общее значение причины здесь накладывается количественная оценка не названных, но подразумевающихся характеристик порождающего события - по сравнению с нормой «слишком сильно», «слишком часто», «слишком много», «слишком долго» и т. д., причем следствие вызвано именно интенсивностью события-1. Оценка выносится с точки зрения говорящего.

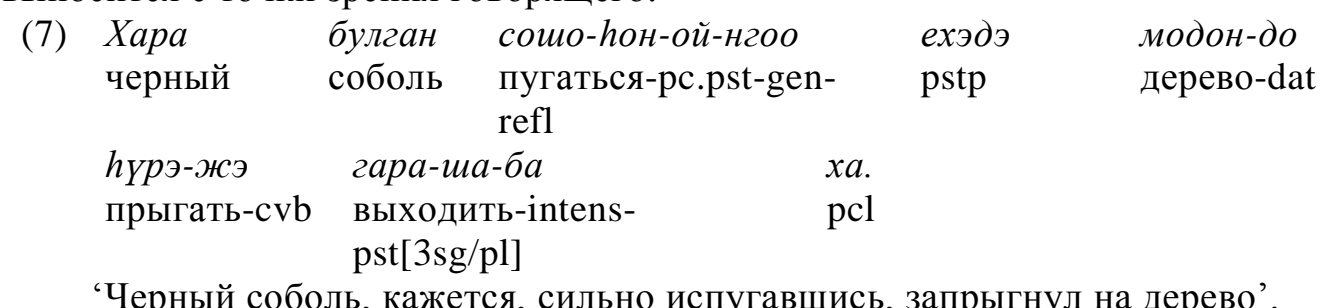


Е. К. Скрибник, Н. Б. Даржаева. Семантика обстоятельственного сложного предложения в бурятском языке и языковая картина мира

\section{3. Конструкции цели с оценочным компонентом}

Конструкции цели также характеризуются дополнительными семантическими параметрами, связанными с оценкой, причем эмоционально окрашенной: оценка цели по способу достижения и значимости. Носителями оценочной характеристики выступают послелоги, сопровождающие причастие будущего времени в родительном падеже: хойноһоо 'за, для того, чтобы', урманда 'лишь бы' (положит.), талаанда 'лишь бы' (неодобр.). Конструкция с послелогом хойноһоо выражает оценочную характеристику не только цели (положительно оцениваемая, значимая), но и способа ее достижения: с точки зрения говорящего либо протагониста, ее можно достичь только через затрату серьезных физических и моральных усилий. Соответственно, лексическое наполнение главной части - это обычно глаголы типа 'стараться', 'трудиться', 'преодолевать трудности' и т. п.

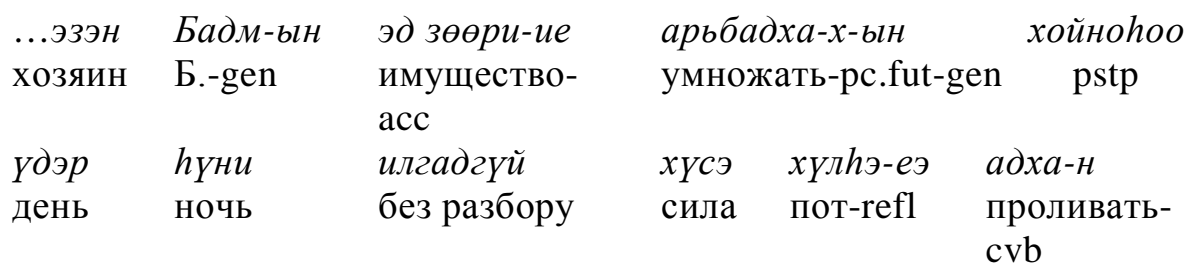

яба-һан-аа һана-жа...

aux-pc.pst-refl вспоминать-cvb

'...вспоминая о том, как он, не разбирая дни и ночи, проливая свой пот, трудился (букв.: ходил) ради того, чтобы приумножить богатство хозяина Бадмы...'

Неоднозначно специализированный послелог урманда (о его причинном значении см. выше - 'в честь того, что...') в целевом употреблении встречается редко; он называет положительную цель, эмоционально весьма значимую для протагониста, и готовность достичь ее любым способом:

\begin{tabular}{|c|c|c|}
\hline $\begin{array}{l}\text { Мори } \\
\text { лошадь- } \\
\text { асс }\end{array}$ & $\begin{array}{l}\text { уна-х-ылt } \\
\text { ехать_верхом-ptcp.fut- } \\
\text { gen }\end{array}$ & $\begin{array}{l}\text { урманда } \\
\text { pstp }\end{array}$ \\
\hline Лодон Л. & $\begin{array}{l}\text { хамараг-ууд-ые } \\
\text { телка-рl-асс }\end{array}$ & $\begin{array}{l}\text { адуул-даг } \\
\text { пасти-рtср.hab }\end{array}$ \\
\hline
\end{tabular}

'Лодон пасет телок ради того, чтобы /лишь бы поскакать на лошади'.

В конструкции с послелогом талаанда 'лишь бы' (неодобр.), как и в случае с урманда, подчеркивается чрезвычайная важность цели для действующего субъекта и готовность достичь ее любым способом. Однако для говорящего такой способ ее достижения, какой назван в главной части, является несколько странным, необычным или неодобряемым: 
ВЕСТНИК БУРЯТСКОГО ГОСУДАРСТВЕННОГО УНИВЕРСИТЕТА ЯЗЫК. ЛИТЕРАТУРА. КУЛЬТУРА

\begin{tabular}{|c|c|c|c|c|c|c|}
\hline \multirow[t]{2}{*}{ (10) } & Ульгам & шударгуy & мор-ёор & xamap & таби-х-ьин & $\begin{array}{l}\text { тала- } \\
\text { анда }\end{array}$ \\
\hline & ходкий & $\begin{array}{l}\text { предан- } \\
\text { ный }\end{array}$ & конь-іns & рысь & $\begin{array}{l}\text { пускать-рс.fut- } \\
\text { gen }\end{array}$ & pstp \\
\hline & хаана-и & ошио-хо & & & & \\
\hline & где-pcl & идти-рс & $\mathrm{ut}[3 \mathrm{sg} / \mathrm{pl}]$ & & & \\
\hline
\end{tabular}

\section{4. Темпоральные конструкции}

В зоне темпоральных конструкций обнаруживаются следующие дополнительные семантические параметры, накладывающиеся на стандартные отношения одновременности, предшествования, следования: прагматическая оценка временных отношений ('полезно') и регулярная оппозиция «несоответствие ожиданиям».

Конструкция одновременности с прагматической оценкой строится послелогом һамбаанда (от һамбаан 'подходящий момент' в дательно-местном падеже); в этой конструкции оценку выносит не говорящий, а протагонист, субъект главной части:

\begin{tabular}{|c|c|c|c|c|c|c|}
\hline (11) & Аламж-ын & гороо & хэ-хэеэ & ошо-һон & $\begin{array}{l}\text { һамба- } \\
\text { анда }\end{array}$ & Самбу. \\
\hline & A. & гороо ${ }^{1}$ & делать-cvb & идти-рс.pst & pstp & C. \\
\hline & $\pi c$ & $2 \ni p$ & тээน-ээ & яара- & ошо-бо & \\
\hline & гама & дом & pstp-refl & спешить-cvb & идти-pst & $3 \mathrm{sg} / \mathrm{pl}]$ \\
\hline
\end{tabular}

'(Воспользовавшись тем, что) пока Аламжа ушел делать гороо, Самбу лама поспешил домой’.

Конструкция одновременности с несоответствием ожиданиям строится послелогом зандаa (от зан(г) 'поведение, привычка' в дательно-местном падеже с субъектно-притяжательным показателем - соответственно, конструкция всегда моносубъектна). Передаваемое значение - главное действие совершается на фоне некоторого действия/состояния, которое с точки зрения говорящего должно было прерваться (предыдущим действием в контексте либо в соответствии с нормативами поведения). Так, в примере (12) работа была прервана начавшейся дракой и говорящий ожидал бы, что вилы будут отложены:

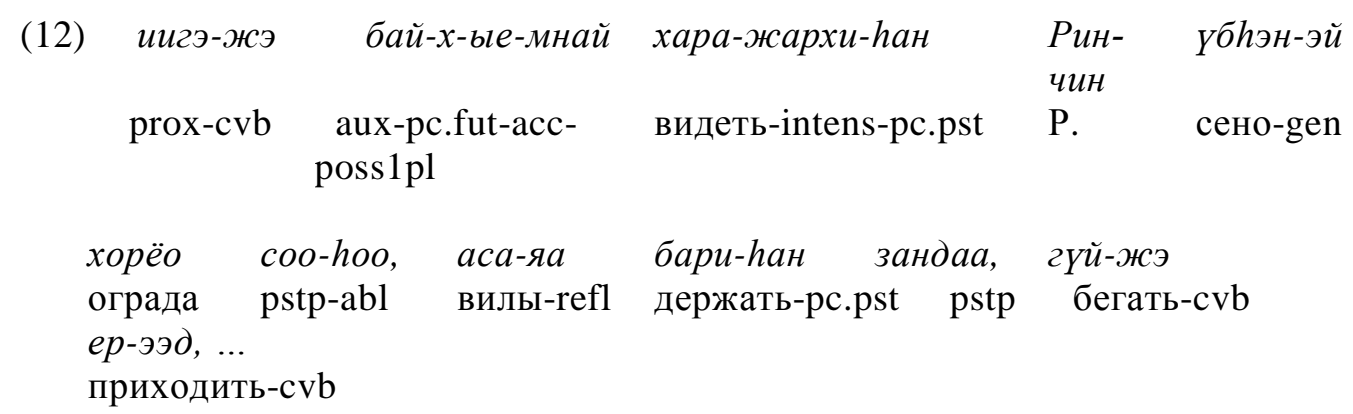

${ }^{1}$ Гороо — ритуальный обход вокруг буддистского храма 
E. К. Скрибник, Н. Б. Даржаева. Семантика обстоятельственного сложного предложения в бурятском языке и языковая картина мира

'Ринчин, увидевший, что я делаю, выбежал из сарая с сеном, всё еще держа вилы’.

В примере (13) тот, кто говорит, по правилам вежливости должен был бы смотреть на собеседника:

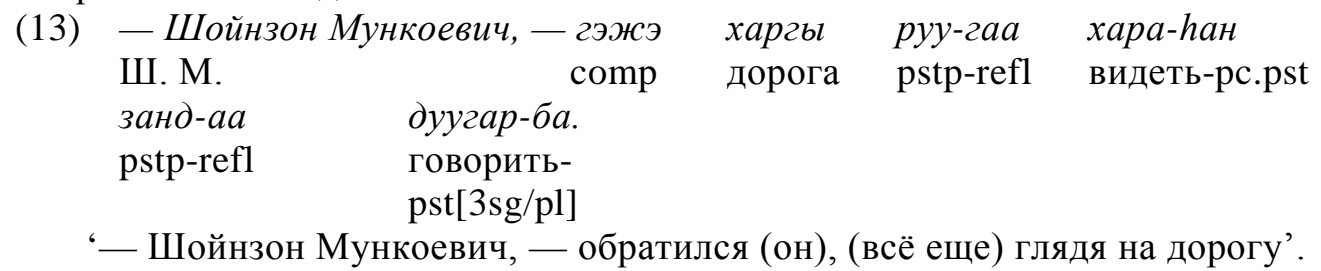

В конструкции предшествования с несоответствием ожиданиям семантика обеспечивается послелогом урид 'прежде, раньше'. Здесь индивидуальным ожиданиям говорящего и/или протагониста либо же общим нормам поведения не соответствует главное действие, причем именно во временных рамках, задаваемых главной частью. Например, в (14) подчеркивается, что все нужно закончить в необычное время - ночью:

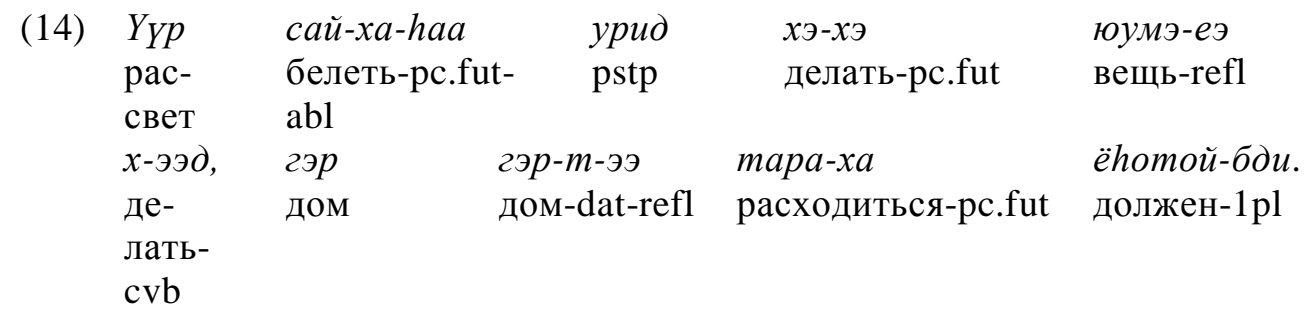

'Мы должны все закончить и разойтись по домам еще до рассвета'.

Часто встречается и значение преждевременного наступления главного действия, которое может отменить намеченное действие зависимой части:

$$
\begin{array}{llll}
\text { ҮҮдэ } & \text { тоншо-хо-hоо-мни } & \text { урид } & \text { тайла-жархи-ба } \\
\text { дверь } & \text { стучать-pc.fut-abl-poss1sg } & \text { pstp } & \text { открыться-intens- } \\
& & & \text { pst[3sg] }
\end{array}
$$

'(Еще) прежде чем я постучал, дверь распахнулась'.

Конструкций следования с несоответствием ожиданиям в бурятском две. Одна из них строится формой причастия прошедшего времени с показателями притяжания; аналогичная халха-монгольская форма -снAA в этой функции рассматривается как деепричастие [10]. В Бурятской грамматике эта конструкция рассматривается как «условный оборот со значением предпосылки», в котором «оттенок неожиданности перерастает в значение противопоставления» [3, c. 147-148]. Действительно, во многих примерах главная часть обозначает неожиданное положение вещей, а зависимая - некоторое действие, например движение, обеспечивающее его восприятие (в русском переводе необходимо добавление 'оказалось, что'). 
(16)

$\begin{array}{llll}\text { Tугаарай } & \text { библио- } & \text { ерэ-hэ-мни, } & \text { хаалтатай } \\ & \text { текэ } & & \\ \text { недавно } & \text { библиотека } & \text { приходить-pс.pst- } & \text { закрытый } \\ & & \text { poss1sg }\end{array}$

бай-гаa

aux-pc.prs[3sg/pl]

'Когда я недавно пришел в библиотеку, она оказалась закрыта'.

Конструкция с так называемым предельным деепричастием на -mAp многозначна, но одним из ее значений является передача последовательности действий, из которых второе не соответствует ожиданиям говорящего либо протагониста. В следующем примере речь идет о молодой женщине, которую застали в бане обнажённой:

$$
\begin{array}{llllll}
\ldots x \text { оёр } & \text { zар-аap-aa } & \text { энэ } & \text { тэрэ } & \text { юумэ-еэ } & \text { халхал-жа } \\
\text { два } & \text { рука-ins-refl } & \text { этот } & \text { тот } & \text { вещь-refl } & \text { прикрывать- } \\
& & & & & \text { cvb }
\end{array}
$$

яда-н бай-тар-аа, таз соо-гоо һуу-ша-ба.

не мочь-cvb aux-cvb-refl таз pstp-refl сидеть-intens-

$\mathrm{pst}[3 \mathrm{sg} / \mathrm{pl}]$

'...безуспешно попытавшись прикрыться обеими руками (букв., прикрывшись и не смочь), (неожиданно) села в таз'.

\section{5. Конструкции образа действия}

В конструкциях образа действия обнаружился прежде всего параметр соответствие/несоответствие индивидуальным ожиданиям либо социальным нормам. Прежде всего это конструкция с уникальным деепричастием «необычного действия» [6, с. 291] на -мгАшАA, передающая прежде всего действия, совер-

\begin{tabular}{|c|c|c|c|c|}
\hline (18) & $\begin{array}{l}\text { Дагба арайхан } \\
\text { Д. кое-как } \\
\text { хэбтэ-мгэшээ } \\
\text { лежать-сvb }\end{array}$ & $\begin{array}{l}\quad \text { тэргэ-д-ээ } \\
\text { телега-dat-refl } \\
\text { боожо-д-оо } \\
\text { вожжи-dat-refl }\end{array}$ & $\begin{array}{l}\text { аһалда-жа } \\
\text { ухватиться-сvb } \\
\text { аһалда-ба } \\
\text { vхватиться-nst }\end{array}$ & $\begin{array}{l}Y p д-е э \partial, \\
\text { успеть-сvb }\end{array}$ \\
\hline
\end{tabular}
шаемые в необычном положении (самые частотные формы - 'стоя', 'сидя', 'лёжа'):

Конструкция образа действия в соответствии с социальными нормами или индивидуальными стереотипами образуется послелогом гуримаар (форма орудного падежа от гурим 'обычай, правило, привычка'):

$\begin{array}{llll}\text { Орон дэлхэй-д-ээ } & \text { саса-даг } & \text { лэ } & \text { гуримаap-aa } \\ \text { местность-dat-refl } & \text { брызгать-ptcp.hab } & \text { pcl } & \text { pstp-refl } \\ \text { саса-жа } & \text { Үрг-өөд... } & & \\ \text { брызгать-сvb } & \text { преподносить-сvb } & & \end{array}$


Е. К. Скрибник, Н. Б. Даржаева. Семантика обстоятельственного сложного предложения в бурятском языке и языковая картина мира

'Побрызгав, как (он) обычно брызгает на местности...' (жертвоприношение местным духам).

Собственно говоря, к этой же группе относится отрицательное деепричастие на -нгүй [11, с. 264], поскольку оно используется в контекстах, где отсутствует некоторое сопровождающее действие, ожидаемое говорящим:

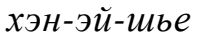
нюур
хара-нгуй
эдеэл-щэ-нэ.
кто-gen-pcl
лицо
видеть-cv.neg
кушать-intens-prs[3sg]

'Набросился на еду, ни на кого не глядя.'

\section{Заключение}

Чрезвычайное богатство бурятских обстоятельственных конструкций обусловлено наличием во всех семантических типах нетривиальных семантических оппозиций, не представленных или слабо представленных в языках SAE: это, во-первых, оценка качественная, количественная и прагматическая, во-вторых, оценка по соответствию/несоответствию ожиданиям. Последнее при ближайшем рассмотрении является одним из компонентов более широкого явления - представления/кодирования в системе сложного предложения социальных норм и шире - динамической картины мира. Таким образом, синтаксис наряду с другими системами языка способен кодировать и транслировать значимые установки, относящиеся к национальной картине мира.

\section{Список глосс}

$\mathrm{ABL}$ - исходный падеж

ACC - винительный падеж

ADJ - прилагательное

AUX - вспомогательный глагол

CAUS - каузатив

СОM - совместный падеж

CVB - деепричастие

DAT - дательно-местный падеж

DIM - уменьшительный суффикс

FUT - будущее время

GEN- родительный падеж

INS - орудный падеж

INTENS - интенсивное действие

NUM.ORD - порядковое числительное

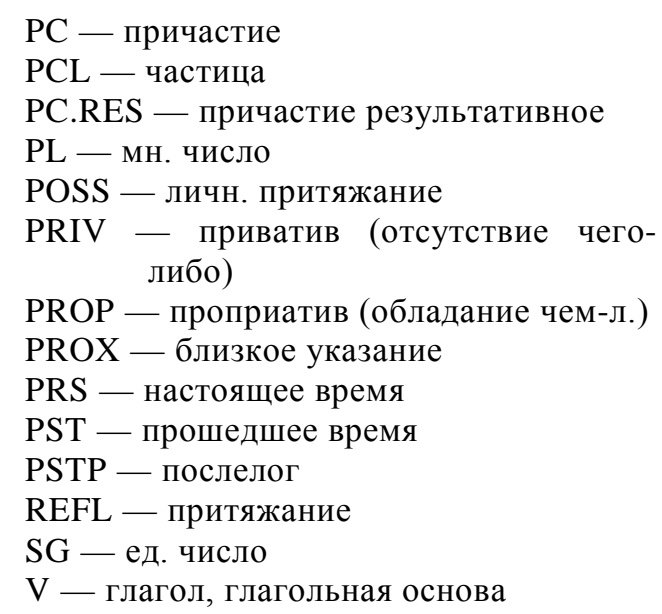

\section{Литература}

1. Апресян Ю. Д. Образ человека по данным языка: попытка системного описания // Вопросы языка. М., 1995. Т. 2. С. 37-67.

2. Бардаханова 3. Д. Охотничья лексика как отражение языковой картины мира монголов // Вестник БГУ. Язык. Литература. Культура. 2019. № 3. С. 84-88.

3. Бертагаев Т. А., Цыдендамбаев Ц. Б. Грамматика бурятского языка. Синтаксис. М.: Восточная литература, 1962. 316 с. 
4. Бухаева Р. В. Этнокультурные стереотипы речевого общения (на материале бурятского языка): автореф. дис. ... д-ра филол. наук. М., 2015. 47 с.

5. Грамматика бурятского языка. Фонетика и морфология. М.: Изд-во восточной литературы, 1962. 340 с.

6. Бертагаев Т. А., Цырендабаев Ц. Б. Грамматика бурятского языка. Синтаксис / под ред. Г. Д. Санжеева. М. Изд-во восточной литературы, 1962. 317 с.

7. Грамматика современного русского литературного языка / под ред. Н. Ю. Шведовой. М.: Наука, 1970. 767 с.

8. Зализняк А. А., Левонтина И. Б., Шмелев А. Д. Ключевые идеи русской языковой картины мира. М.: Языки славянской культуры, 2005. 527 с.

9. Корнилов О. А. Языковые картины мира как производные национальных менталитетов. 2-е изд., испр. и доп. М.: ЧеРо, 2003. 349 с.

10. Наделяев В. М. Современный монгольский язык. Морфология. Новосибирск: Наука, 1988. 113 с.

11. Скрибник Е. К., Даржаева Н. Б. Грамматика бурятского языка. Синтаксис сложного (полипредикативного) предложения. Улан-Удэ: Изд-во БНЦ СО РАН, 2016. Т. І. 315 с.

12. Тагарова Т. Б. Образ человека в сравнительных конструкциях бурятского языка: эмоционально-оценочный аспект // Вестник Северного (Арктического) федерального унта. Сер.: Гуманитарные и социальные науки. 2018. № 5. С. 92-102.

13. Телия В. Н. Метафоризация и ее роль в создании языковой картины мира // Роль человеческого фактора в языке. Язык и картина мира. М., 1988. С. 173-203.

14. Шкуропацкая М. Г., Даваа Ундармаа. Национальная языковая картина мира как компонент языкового сознания русской и монгольской языковой личности (сопоставительный аспект) // Вестн. Том. гос. ун-та. Филология. 2016. № 1(39). С. 80-95.

15. Шкуропацкая М. Г., Даваа Ундармаа. Языковая картина мира как отражение национальной ментальности (на материале зоонимов в русском и монгольском языках) // Сибирский филологический журнал. 2018. № 2. С. 141-156.

16. Du Bois, John (1985). 'Competing motivations', in John Haiman (ed.) Iconicity in syntax. Amsterdam: Benjamins, 343-365.

17. Bednarek, Monika (2009). 'Dimensions of evaluation: cognitive and linguistic perspectives’, Pragmatics \& Cognition 17/1: 146-175.

\section{SEMANTICS of BURYAT ADVERBIAL CLAUSES and LINGUISTIC WORLDVIEW}

(C) Elena K. Skribnik

Prof. Dr.habil.

Ludwig-Maximilians-Universität München, Ludwigstrasse 31/ III, D-80539 München, Deutschland skribnik@lmu.de

\section{(C) Nadezhda B. Darzhaeva}

Science Doctor in Philology, Research Associate, Institute for Mongolian, Buddhist and Tibetan Studies of the Siberian Branch of the Russian Academy of Sciences (IMBTS SB RAS)

6, Sakhyanovoi Str., Ulan-Ude, 670047, Russia dnadezhda@mail.ru 
Е. К. Скрибник, Н. Б. Даржаева. Семантика обстоятельственного сложного предложения в бурятском языке и языковая картина мира

Abstract. This paper presents some results of of research on the system of adverbial clauses in Buryat as it reflects some elements of the national 'linguistic picture of the world'. Buryat (as well as other Mongolian languages) is characterized by an unusually large number of constructions with adverbial clauses in practically all semantic types; this suggests some additional semantic features that are not, or less consistently, coded in better-known European languages.

Our analysis has shown that the relations between events in Buryat are expressed not only neutrally, but with two additional types of features: a regular correlation of described relations with social norms and individual expectations ('in accordance with' vs. 'against norms/expectations'), as well as evaluation ('neutral' vs. 'evaluated by the speaker: qualitatively, quantitatively, or pragmatically'). It means that such important elements of the national worldview like social norms and values or dynamic scenarios for natural and social events are coded also on the syntactic level.

Keywords: Mongolic syntax, complex sentence, adverbial clauses, semantics of syntax, evaluation, expectations, linguistic worldview.

Статья поступила в редакциюо 13.11.2020; одобрена после рецензирования 25.11.2020; принята к публикащии 24.12.2020. 